\title{
Value-addition of Beef Meat By-products: Lipid Characterization by Chromatographic Techniques
}

\author{
Silvia Marzocchi ${ }^{1}$, Federica Pasini ${ }^{2 *}$, Chiara Baldinelli ${ }^{3}$ and Maria Fiorenza Caboni ${ }^{1,2}$ \\ ${ }^{1}$ Department of Agricultural and Food Sciences and Technologies, University of Bologna, Piazza Goidanich 60, I-47521 Cesena (FC), ITALY \\ ${ }^{2}$ Interdepartmental Centre for Agri-Food Industrial Research (CIRI AgriFood), University of Bologna, via Quinto Bucci 336, I-47521 Cesena (FC), \\ ITALY \\ ${ }^{3}$ Inalca S.p.A., via Spilamberto 30/C, 41014 Castelvetro (MO), ITALY
}

\begin{abstract}
The lipid characterization of storage fat, subcutaneous fat and bone marrow, originated from three different bovine categories, calf, young bull and cow, was carried out in order to develop a re-use of these by-products. After the lipid extraction, the compositions in fatty acids, triacylglycerols and cholesterol were determined by GC-FID. A total of 25 fatty acids were identified in all by-products; the oleic acid was the preponderant component, followed by palmitic, stearic, palmitoleic, linoleic and myristic acid. The long chain triacylglycerols (T48, T50 and T52) were the main products, especially in the cow's by-products. The subcutaneous fat of all animals showed the highest cholesterol content, whereas it was present in low amount in the others. Phospholipids were analysed in bone marrow of all the animals and phosphatidylcholine was the most abundant compound. Because of the high fat content and essential fatty acids and the low cholesterol amount, storage fat and bone marrow could represent a valuable lipid resource in food and pharmaceutical industry.
\end{abstract}

Key words: beef by-products, cholesterol, fatty acids, phospholipids, triacylglycerols

\section{Introduction}

Most animal by-products originate during slaughter of cattle for human consumption, the production of dairy products, the disposal of carcasses and disease control. Animal by-products mean entire body or parts of it, products of animal origin or also products which are not for human consumption, including oocytes, embryos and semen(Regulation(EC) No 1069/2009). In order to reduce by-products generation, different industrial processes are used in the meat industry, but usually these by-products are discarded as waste or used for low-value purpose ${ }^{1)}$. The large amounts of unused by-products cause a big loss of profit and an expense for their disposal, generating an increase in the cost of meat production. The use of these byproducts not only increases profits, but also deals with the problems of environmental pollution associated with their disposal $^{2}$. In particular, fat obtained from animal by-products can be melted fractionated and used in numerous cosmetic applications, such as the formulation of body lotions or other bath products. The fatty acids are used in numerous chemical processes including the polymerization of rubber and plastic, the production of fabric softeners, lubricants and plasticizers. Collagen, gelatin and glycerol are employed as ingredients to produce antifreeze substances, surfactants, paints, adhesives, detergents, as well as for pharmaceuticals ${ }^{3)}$.

The fat percentage in beef carcasses ranging from 30 to $40 \%$, depending on endogenous and exogenous factors (ISMEA, 2015). The fat of the meat can be classified into different types: subcutaneous fat, which is formed by large adipocytes in the connective tissue and it is a reserve of energy on the surface of muscles; intermuscular fat, which is located in different muscles in the same anatomic part and it is mainly composed by triacylglycerols and saturated fatty acids as the subcutaneous fat. Intramuscular fat, the fat marbling, is located between the muscle fibres and the fibre bundles and it mainly influences the nutritional characteristics of meat; finally, intracellular fat is located within muscle fibres and it is particularly rich in phospholipids ${ }^{4}$. Half of the fatty acid total content of bovine meat is mainly composed by saturated fatty acids. The pattern of these compounds is partly affected by the animal species, breed, age and farmed technique. Unlike monogastric animals, the microflora in the rumen is able to hydrogenate most of the unsaturated fatty acids introduced by feeding, increasing saturated lipids ${ }^{5}$. Several studies report the positive bio-

*Correspondence to: Federica Pasini, Interdepartmental Centre for Agri-Food Industrial Research (CIRI AgriFood), University of Bologna, via Quinto Bucci 336, I-47521 Cesena (FC), ITALY

E-mail: federica.pasini5@unibo.it

Accepted September 8, 2017 (received for review June 20, 2017)

Journal of Oleo Science ISSN 1345-8957 print / ISSN 1347-3352 online

http://www.jstage.jst.go.jp/browse/jos/ http://mc.manusriptcentral.com/jjocs 


\section{S. Marzocchi, F. Pasini, C. Baldinelli et al.}

logical activities of food phospholipids on human health ${ }^{6,7)}$ by virtue of both lipophilic and hydrophilic properties ${ }^{8,9)}$. The phospholipid content in beef muscle ranged between 0.5 and $0.6 \mathrm{~g} / 100 \mathrm{~g}$ of fresh muscle ${ }^{10)}$.

The aim of this study is a screening of the lipid quality and composition of different by-products produced by bovine meat industry. The valorisation of these wastes is an important goal for the profit of the meat industry and for the environmental impact, avoiding their disposal. At the same time, literature is lacking in works on lipid quality of beef by-products, so these data can be of great importance in the promotion of their re-utilization, developing new technological applications.

\section{Materials and Methods 2.1 Samples}

A total of three by-products produced by a slaughterhouse in the north of Italy were analysed: storage fat, subcutaneous fat and bone marrow. These by-products were obtained from three Friesian bovine categories, differing in age and morphology, that is calf (CA), young bull(YB) and cow $(\mathrm{CO})$. Calf was fed only with milk due to the young slaughter age. Young bull and cow were fed with a traditional diet, based on the use of concentrate and hay (dry feeding period) and fresh forage (fresh forage feeding period) without use of silages. The different categories were slaughtered according to slaughter legislation: calves were slaughtered at 5-6 months old, 200-250 kg; young bulls at 16-18 months old, 600-650 kg and cows at 14-18 months old, 420-480 kg. These samples are the result of all the waste obtained at the end of a working day, approximately thousand animals for each category. Before the lipid extraction, in order to obtain a homogeneous sampling and to facilitate the breaking of fat cells, all by-products were dissected and crumbled with knives and blade blender and then sonicated at room temperature.

\subsection{Lipid extraction}

The lipid fraction of the samples was extracted using the procedure described by Folch et al. ${ }^{11)}$, which has been slightly modified as reported elsewhere ${ }^{12)}$. Each extraction was carried out three times for each by-product $(n=9$ for animal sample).

\subsection{Fatty acid analysis}

The fatty acid composition was determined as fatty acid methyl esters (FAMEs) by capillary gas chromatography analysis after alkaline treatment ${ }^{13)}$. Methyl tridecanoate (C13:0, $2 \mathrm{mg} / \mathrm{mL}$ ) was used as internal standard and FAMEs were measured on a GC 2010 Plus gas chromatograph (Shimadzu Corporation, Kyoto, Japan) equipped with a flame ionisation detector (FID) and an AOC-20s auto sampler (Shimadzu Corporation), according to Verardo et $a l{ }^{14)}$ with slight modifications. The FAMEs were analysed using a BPX70 fused silica capillary column $(10 \mathrm{~m} \times 0.1 \mathrm{~mm}$ i.d. $0.2 \mu \mathrm{m}$ film thickness; SGE Analytical Science. Ringwood. VIC. Australia). The injector and flame ionization detector temperatures were set at $250^{\circ} \mathrm{C}$. Hydrogen was used as carrier gas at a flow rate of $0.8 \mathrm{~mL} / \mathrm{min}$. The oven temperature was held at $50^{\circ} \mathrm{C}$ for $0.2 \mathrm{~min}$, increased to $175^{\circ} \mathrm{C}$ at $120^{\circ} \mathrm{C} / \mathrm{min}$, held at $175^{\circ} \mathrm{C}$ for 2 min and finally increased from 175 to $220^{\circ} \mathrm{C}$ at $20^{\circ} \mathrm{C} / \mathrm{min}$. Samples were injected in split mode $(0.3 \mu \mathrm{L})$ with a split ratio set at 1:100. Peak identification was accomplished by comparing peak retention time with GLC-463 standard mixture from Nu-Check (Elysian. MN. USA) and FAME 189-19 standard mixtures from Sigma-Aldrich Chemicals (St. Louis, MO, USA) and expressed as weight percentage of total FAMEs. FAMEs composition was measured in 2 replicates for each lipid extract $(n=6)$ and each analysis lasted 7 minutes.

\subsection{Triacylglycerols analysis}

Triacylglycerols (TGs) analysis was carried out with the injection of $1.0 \mu \mathrm{L}$ of solution $(10 \mathrm{mg} / \mathrm{mL}$ of fat in $n$-hexane) into a GC-2010 Plus gas chromatograph (Shimadzu Corporation, Kyoto, Japan) equipped with a flame ionisation detector (FID) and an AOC-20s auto sampler (Shimad$\mathrm{zu}$ Corporation) according to Guerra et $a l^{15)}$, with slight modification. TGs separation was performed with an Rtx-65 TG fused silica capillary column $(30 \mathrm{~m} \times 0.25 \mathrm{~mm} \times$ $0.10 \mu \mathrm{m}$ film thickness) with 35\% dimethyl, 65\% diphenyl polysiloxane (Restek, Chromatography Products, Superchrom Milano, Italy). The initial oven temperature of $140^{\circ} \mathrm{C}$ was raised to $360^{\circ} \mathrm{C}$ at a rate of $25^{\circ} \mathrm{C} / \mathrm{min}$ and was held at $360^{\circ} \mathrm{C}$ for $5 \mathrm{~min}$. The injector and detector temperatures were set at $360^{\circ} \mathrm{C}$. The hydrogen flow rate was $3.84 \mathrm{~mL} /$ min. The split ratio was 1:30. TGs were identified based on retention time of a standard mixture injected with the same method and from the comparison with the chromatograms reported in literature. The methodology for the analysis was based on the separation of classes of TGs according to the total number of carbon atoms $(\mathrm{CN}$; sum of the three FAs) and each class has been quantified as a percentage of total TGs content. TGs composition was measured in 2 replicates for each lipid extract $(n=6)$ and each analysis had a duration of 26 minutes.

\subsection{Cholesterol determination}

Cholesterol was collected by cold saponification at room temperature ${ }^{16)}$ after addition of $500 \mu \mathrm{L}$ of internal standard (dihydrocholesterol, $2 \mathrm{mg} / \mathrm{mL}$ ) to $250 \mathrm{mg}$ of fat. The unsaponificable fraction was evaporated by vacuum evaporator, silylated ${ }^{17)}$ and dried again under gentle nitrogen flow. After redissolution in $500 \mu \mathrm{L}$ of $n$-hexane, $1 \mu \mathrm{L}$ was injected into a GC 2010 Plus gas chromatograph (Shimadzu. Kyoto. Japan), equipped with a flame ionization detector (FID) 
and an AOC-20i autosampler, according to the method reported by Guerra et $a l .{ }^{18)}$. A Rxi-5ms fused silica capillary $\operatorname{column}(10 \mathrm{~m} \times 0.10 \mathrm{~mm}$ i.d. $\times 0.10 \mu \mathrm{m}$ film thickness $)$ from Restek (Restek Corporation, Bellefonte, USA) was used. Oven temperature was set at $240^{\circ} \mathrm{C}$ and the injector and detector temperatures were $325^{\circ} \mathrm{C}$. The column flow of hydrogen was $0.4 \mathrm{~mL} / \mathrm{min}$ and the injection volume was 0.30 $\mu \mathrm{L}$, with a split ratio of 1:50. Cholesterol content was measured in 2 replicates for each lipid extract $(n=6)$ and was expressed in $\mathrm{mg}$ cholesterol/kg of fat; and each analysis lasted 15 minutes.

\subsection{Phospholipids determination}

The phospholipids (PLs) extraction was made according to Avalli and Contarini ${ }^{19)}$ by a purification of the lipid extracts with solid-phase extraction (SPE) cartridges. The identification and quantification of PL classes was performed using an Agilent liquid chromatography HP 1200 Series, (HPLC; Agilent Technologies, Palo Alto, CA, USA) combined with an evaporative light-scattering detector (ELSD; PL-ELS1000, Polymer laboratories, Church Stretton, Shropshire, UK). The separation of PLs was achieved using a silica column, $150 \mathrm{~mm} \times 3 \mathrm{~mm}$ with $3 \mu \mathrm{m}$ particle diameter(Phenomenex, Torrance, CA, USA) and applying the method by Verardo et $a l .{ }^{20)}$ with some modifications. The HPLC system was controlled by Agilent Chem-Station software (Agilent Technologies), whilst chromatogram and data processing were assessed by ClarityLite(ver. 2.4.0.190, Data- Apex, Praha, Czech Republic). PLs were identified by comparison with pure standards and quantified with external calibration curves, prepared separately for each phospholipid identified (from 1 to $500 \mathrm{mg} / \mathrm{mL}$ of PE, PI, PS, PC and SM). Each analysis lasted 36 minutes.

\subsection{Statistical analysis}

Relative standard deviation was obtained, where appropriate, for all data collected. One-way analysis of variance (ANOVA) was evaluated using Statistica 8 software (2006, StatSoft, Tulsa, OK, USA). The differences between the means of data for the three different by-products (storage fat, subcutaneous fat and bone marrow) and for the three different animals (calf, young bull and cow) were compared at the $5 \%$ level of significance $(p<0.05)$ using Tukey honest significant difference (HSD) test.

\section{Results and Discussion}

\subsection{Total lipid content of by-products}

The fat content of the different by-products is reported in Table 1 and it is expressed as percentage (\%) on the total fresh weight of the sample. The calf's storage fat and bone marrow showed a significant $(p<0.05)$ lower fat content compared to the other two animals. This result re-
Table 1 Fat content of the different by-product samples.

\begin{tabular}{cccc}
\hline & CA & YB & CO \\
\hline Storage fat & $61.4 \pm 4.1^{\mathrm{b}}$ & $81.6 \pm 4.6^{\mathrm{a}}$ & $83.6 \pm 0.5^{\mathrm{a}}$ \\
Subcutaneous fat & $8.2 \pm 0.7^{\mathrm{a}}$ & $22.3 \pm 8.8^{\mathrm{a}}$ & $14.8 \pm 7.0^{\mathrm{a}}$ \\
Bone marrow & $70.5 \pm 1.1^{\mathrm{b}}$ & $86.6 \pm 3.4^{\mathrm{a}}$ & $89.8 \pm 0.9^{\mathrm{a}}$ \\
\hline
\end{tabular}

Abbreviations: CA, calf; YB, young bull; CO, cow. Data (means $\pm \mathrm{SD})$ are expressed in percentage $(\%)$; results of the analysis of variance by Tukey's test are shown: $p<0.05$, lowercase letters on the same row show significantly different values within each by-product for the three animals.

flects the different characteristics of the animals in regard to their age, morphology and feeding ${ }^{5)}$ in addition to the cut and degree of trimming ${ }^{21)}$. On the other hand, young bull $(\mathrm{YB})$ and cow $(\mathrm{CO})$ did not show significant differences $(p<$ 0.05 ) between them with more than $80 \%$ of storage fat content and $85 \%$ of bone marrow.

Differently, the subcutaneous fat was present in not different amounts $(p<0.05)$ among the animal samples. For this by-product, the repeatability of the data was poor probably due to the non-homogeneous matrix. In fact, the standard deviations of these data were very high, causing a flattening of the differences between samples.

\subsection{Fatty acid composition of by-products}

A total of 25 individual fatty acids were identified and quantified in all samples by fast GC-FID analysis, within a run time less than $7 \mathrm{~min}$, due to a fast GC-FID system.

As shown in Table 2, the predominant fatty acid in all by-products of the different animals was oleic acid (C18:1 cis 9 ), ranging from about 32 to $46 \%$. Palmitic acid(C16:0) constituted the second major fatty acid detected $(\sim 20$ $28 \%$ ), followed by stearic acid (C18:0, 10-19\%), palmitoleic acid (C16:1 cis, $\sim 2-5 \%)$, myristic acid (C14:0, $2-4 \%)$ and linoleic acid (C18:2 n6, 2-10\%).

In the storage fat, the saturated fatty acids (SFA) were present in significantly $(p<0.05)$ greater amounts in calf and young bull (46.76\% and $47.62 \%)$, whereas mono-unsaturated fatty acids (MUFA) were more abundant in cow, in the amount of $55.70 \%$. Polyunsaturated fatty acids (PUFA)were present in low concentrations in all animal samples, accounting for 5.21\%, 3.81\% and 3.50\% for CA, YB and CO, respectively. These trends reflect those of the main individual fatty acids: CO showed the highest content of oleic acid (44.78\%) and palmitoleic acid (5.13\%), whereas YB and CA presented the main content of stearic $\operatorname{acid}(16.64 \%)$ and palmitic acid $(26.44 \%)$, respectively. Besides, CA sample had the highest concentration in the C18:2 n6. According to De Smet et al. ${ }^{22)}$ and Brugiapaglia et $a l{ }^{23)}$ about the investigation on the fatty acid profile of Longissimus thoracis muscle from different Belgian and Italian young bulls, SFA was the predominant class followed by MUFA and PUFA. For SFA class our results (range 


\section{S. Marzocchi, F. Pasini, C. Baldinelli et al.}

Table 2 Fatty acids composition of by-products.

\begin{tabular}{|c|c|c|c|c|c|c|c|c|c|}
\hline \multirow{2}{*}{ FA } & \multicolumn{3}{|c|}{ Storage fat } & \multicolumn{3}{|c|}{ Subcutaneous fat } & \multicolumn{3}{|c|}{ Bone marrow } \\
\hline & $\mathrm{CA}$ & YB & $\mathrm{CO}$ & $\mathrm{CA}$ & YB & $\mathrm{CO}$ & $\mathrm{CA}$ & YB & $\mathrm{CO}$ \\
\hline C12:0 & $0.18 \pm 0.14^{\mathrm{a}} \mathrm{B}$ & $0.11 \pm 0.01^{\mathrm{aB}}$ & $0.09 \pm 0.02^{\mathrm{aA}}$ & $0.11 \pm 0.01^{\mathrm{aB}}$ & $0.07 \pm 0.01^{\mathrm{bC}}$ & $0.07 \pm 0.00^{\mathrm{bB}}$ & $0.42 \pm 0.03^{\text {aA }}$ & $0.19 \pm 0.01^{\mathrm{bA}}$ & $0.07 \pm 0.01^{\mathrm{cB}}$ \\
\hline C14:0 & $3.57 \pm 0.52^{\mathrm{aA}}$ & $3.73 \pm 0.11^{\mathrm{aB}}$ & $3.04 \pm 0.03^{\mathrm{bA}}$ & $2.81 \pm 0.05^{\mathrm{aB}}$ & $2.36 \pm 0.10^{\mathrm{bC}}$ & $2.35 \pm 0.15^{\mathrm{bB}}$ & $2.95 \pm 0.03^{\mathrm{bB}}$ & $4.23 \pm 0.09^{\mathrm{aA}}$ & $1.61 \pm 0.03^{\mathrm{cC}}$ \\
\hline C14:1c & $0.81 \pm 0.06^{\mathrm{cA}}$ & $0.94 \pm 0.06^{\mathrm{bB}}$ & $1.87 \pm 0.06^{\mathrm{aA}}$ & $0.81 \pm 0.05^{\mathrm{bA}}$ & $1.12 \pm 0.19^{\mathrm{aA}}$ & $0.81 \pm 0.09^{\mathrm{bB}}$ & $0.72 \pm 0.02^{\mathrm{bB}}$ & $0.91 \pm 0.03^{\mathrm{aB}}$ & $0.52 \pm 0.04^{\mathrm{cC}}$ \\
\hline C15:0 & $0.48 \pm 0.03^{\mathrm{bA}}$ & $0.66 \pm 0.03^{\mathrm{aA}}$ & $0.38 \pm 0.01^{\mathrm{cB}}$ & $0.41 \pm 0.02^{\mathrm{bB}}$ & $0.55 \pm 0.13^{\mathrm{aA}}$ & $0.56 \pm 0.03^{\mathrm{aA}}$ & $0.17 \pm 0.01^{\mathrm{cC}}$ & $0.66 \pm 0.01^{\mathrm{aA}}$ & $0.54 \pm 0.01^{\mathrm{bA}}$ \\
\hline $\mathrm{C} 15: 1 \mathrm{c}$ & $0.10 \pm 0.01^{\text {БВ }}$ & $0.14 \pm 0.01^{\mathrm{aC}}$ & $0.15 \pm 0.03^{\mathrm{aB}}$ & $0.12 \pm 0.01^{\mathrm{bA}}$ & $0.28 \pm 0.03^{\mathrm{aA}}$ & $0.27 \pm 0.01^{\mathrm{aA}}$ & $0.05 \pm 0.01^{\mathrm{cC}}$ & $0.23 \pm 0.01^{\mathrm{bB}}$ & $0.26 \pm 0.01^{\mathrm{aA}}$ \\
\hline C16:0 & $26.44 \pm 0.66^{\mathrm{aA}}$ & $24.92 \pm 0.65^{\mathrm{bB}}$ & $25.63 \pm 0.19^{\mathrm{abB}}$ & $25.03 \pm 0.46^{\mathrm{cB}}$ & $27.06 \pm 0.58^{\mathrm{bA}}$ & $28.46 \pm 0.71^{\mathrm{aA}}$ & $20.10 \pm 0.03^{\mathrm{cC}}$ & $27.73 \pm 0.21^{\mathrm{aA}}$ & $24.13 \pm 0.25^{\mathrm{bC}}$ \\
\hline C16:1 trans & $0.29 \pm 0.05^{\mathrm{aB}}$ & $0.24 \pm 0.02^{\mathrm{abB}}$ & $0.20 \pm 0.06^{\mathrm{bB}}$ & $0.32 \pm 0.03^{\mathrm{aB}}$ & $0.25 \pm 0.05^{\mathrm{bB}}$ & $0.26 \pm 0.01^{\mathrm{bB}}$ & $0.57 \pm 0.05^{\mathrm{aA}}$ & $0.40 \pm 0.03^{\mathrm{bA}}$ & $0.36 \pm 0.04^{\mathrm{bA}}$ \\
\hline C16:1 cis & $3.62 \pm 0.36^{\mathrm{bA}}$ & $3.71 \pm 0.17^{\mathrm{bA}}$ & $5.13 \pm 0.10^{\mathrm{aA}}$ & $3.31 \pm 0.08^{\mathrm{aAB}}$ & $3.90 \pm 1.17^{\mathrm{aA}}$ & $3.26 \pm 0.49^{\mathrm{aB}}$ & $3.20 \pm 0.10^{\mathrm{aB}}$ & $2.12 \pm 0.09^{\mathrm{bB}}$ & $1.62 \pm 0.11^{\mathrm{cC}}$ \\
\hline C17:0 & $1.06 \pm 0.06^{\mathrm{bA}}$ & $1.57 \pm 0.04^{\mathrm{aA}}$ & $0.85 \pm 0.03^{\mathrm{CB}}$ & $0.94 \pm 0.04^{\mathrm{bB}}$ & $1.15 \pm 0.26^{\mathrm{abB}}$ & $1.34 \pm 0.09^{\mathrm{aA}}$ & $0.51 \pm 0.01^{\mathrm{cC}}$ & $1.16 \pm 0.01^{\mathrm{bB}}$ & $1.37 \pm 0.01^{\mathrm{aA}}$ \\
\hline C17:1 & $0.68 \pm 0.07^{\mathrm{c}}$ & $1.11 \pm 0.02^{\mathrm{aA}}$ & $0.95 \pm 0.04^{\mathrm{bA}}$ & $0.60 \pm 0.02^{\mathrm{cB}}$ & $0.81 \pm 0.07^{\mathrm{aB}}$ & $0.67 \pm 0.02^{\mathrm{bB}}$ & $0.42 \pm 0.03^{\mathrm{cC}}$ & $0.50 \pm 0.01^{\mathrm{bC}}$ & $0.65 \pm 0.04^{\mathrm{aB}}$ \\
\hline C18:0 & $15.03 \pm 0.79^{\mathrm{bB}}$ & $16.64 \pm 0.52^{\mathrm{aAB}}$ & $10.82 \pm 0.11^{\mathrm{cB}}$ & $17.21 \pm 0.33^{\mathrm{aA}}$ & $14.33 \pm 4.03^{\mathrm{aB}}$ & $16.81 \pm 0.86^{\mathrm{aA}}$ & $10.93 \pm 0.16^{\mathrm{cC}}$ & $19.44 \pm 0.31^{\mathrm{aA}}$ & $17.57 \pm 0.38^{\mathrm{bA}}$ \\
\hline C18:1 trans & $8.52 \pm 1.19^{\mathrm{aA}}$ & $5.14 \pm 0.14^{\mathrm{bA}}$ & $1.21 \pm 0.06^{\mathrm{CC}}$ & $3.38 \pm 0.19^{\mathrm{aB}}$ & $1.59 \pm 0.34^{\mathrm{bC}}$ & $1.72 \pm 0.11^{\mathrm{bB}}$ & $1.26 \pm 0.16^{\mathrm{cC}}$ & $3.52 \pm 0.31^{\mathrm{aB}}$ & $2.57 \pm 0.19^{\mathrm{bA}}$ \\
\hline $\mathrm{C} 18: 1$ cis 9 & $32.22 \pm 1.13^{\mathrm{cC}}$ & $36.81 \pm 0.61^{\mathrm{bB}}$ & $44.78 \pm 0.63^{\mathrm{aA}}$ & $37.13 \pm 0.54^{\mathrm{bB}}$ & $40.90 \pm 3.70^{\mathrm{aA}}$ & $37.57 \pm 1.24^{\mathrm{abc}}$ & $45.97 \pm 0.41^{\mathrm{aA}}$ & $33.41 \pm 0.25^{\mathrm{cC}^{\mathrm{C}}}$ & $43.00 \pm 0.58^{\mathrm{bB}}$ \\
\hline $\begin{array}{c}\text { C18:2 trans } \\
\text { trans }\end{array}$ & $0.31 \pm 0.06^{\mathrm{cA}}$ & $0.55 \pm 0.02^{\mathrm{aB}}$ & $0.40 \pm 0.02^{\mathrm{bB}}$ & $0.32 \pm 0.04^{\mathrm{aA}}$ & $0.33 \pm 0.02^{\mathrm{ac}}$ & $0.29 \pm 0.01^{\mathrm{aC}}$ & $0.00 \pm 0.00^{\mathrm{cB}}$ & $0.64 \pm 0.04^{\mathrm{aA}}$ & $0.44 \pm 0.00^{\mathrm{bA}}$ \\
\hline $\mathrm{C} 18: 2 n 6$ & $3.81 \pm 0.87^{\mathrm{aC}}$ & $1.85 \pm 0.12^{\mathrm{bB}}$ & $1.41 \pm 0.09^{\mathrm{bC}}$ & $4.69 \pm 0.26^{\mathrm{aB}}$ & $2.31 \pm 0.35^{\mathrm{bA}}$ & $2.53 \pm 0.08^{\mathrm{bB}}$ & $10.56 \pm 0.09^{\mathrm{aA}}$ & $2.39 \pm 0.03^{\mathrm{cA}}$ & $3.08 \pm 0.22^{\mathrm{bA}}$ \\
\hline $\begin{array}{c}\mathrm{C} 18: 3 n 6+ \\
\mathrm{C} 19: 0\end{array}$ & $0.12 \pm 0.01^{\mathrm{bB}}$ & $0.27 \pm 0.02^{\mathrm{aB}}$ & $0.35 \pm 0.09^{\mathrm{aA}}$ & $0.23 \pm 0.06^{\mathrm{bA}}$ & $0.33 \pm 0.03^{\mathrm{aA}}$ & $0.27 \pm 0.02^{\mathrm{abA}}$ & $0.17 \pm 0.04^{\mathrm{bB}}$ & $0.20 \pm 0.02^{\mathrm{bC}}$ & $0.27 \pm 0.03^{\mathrm{aA}}$ \\
\hline $\mathrm{C} 18: 3 n 3$ & $0.24 \pm 0.09^{\mathrm{aB}}$ & $0.18 \pm 0.01^{\mathrm{aC}}$ & $0.18 \pm 0.03^{\mathrm{ac}}$ & $0.17 \pm 0.02^{\mathrm{bB}}$ & $0.41 \pm 0.06^{\mathrm{aB}}$ & $0.44 \pm 0.02^{\mathrm{aA}}$ & $0.50 \pm 0.00^{\mathrm{bA}}$ & $0.68 \pm 0.02^{\mathrm{aA}}$ & $0.32 \pm 0.02^{\mathrm{cB}}$ \\
\hline CLA & $0.37 \pm 0.05^{\mathrm{cB}}$ & $0.58 \pm 0.03^{\mathrm{aB}}$ & $0.48 \pm 0.06^{\mathrm{bB}}$ & $0.60 \pm 0.02^{\mathrm{aA}}$ & $0.59 \pm 0.04^{\mathrm{aB}}$ & $0.52 \pm 0.02^{\mathrm{bB}}$ & $0.23 \pm 0.02^{\mathrm{cC}}$ & $0.70 \pm 0.03^{\mathrm{aA}}$ & $0.60 \pm 0.02^{\mathrm{bA}}$ \\
\hline $\mathrm{C} 20: 1$ & $0.27 \pm 0.05^{\mathrm{bB}}$ & $0.21 \pm 0.02^{\mathrm{bC}}$ & $0.47 \pm 0.04^{\mathrm{aA}}$ & $0.33 \pm 0.02^{\mathrm{bA}}$ & $0.43 \pm 0.06^{\mathrm{aA}}$ & $0.40 \pm 0.03^{\mathrm{aB}}$ & $0.37 \pm 0.03^{\mathrm{aA}}$ & $0.29 \pm 0.03^{\mathrm{bB}}$ & $0.37 \pm 0.02^{\mathrm{aB}}$ \\
\hline $\mathrm{C} 20: 2 n 6$ & $0.08 \pm 0.02^{\mathrm{abB}}$ & $0.09 \pm 0.02^{\mathrm{aA}}$ & $0.05 \pm 0.01^{\mathrm{bA}}$ & $0.09 \pm 0.02^{\mathrm{aB}}$ & $0.05 \pm 0.01^{\mathrm{bB}}$ & $0.06 \pm 0.01^{\mathrm{bA}}$ & $0.17 \pm 0.01^{\mathrm{aA}}$ & $0.00 \pm 0.00^{\mathrm{bC}}$ & $0.00 \pm 0.00^{\mathrm{bB}}$ \\
\hline $\mathrm{C} 20: 3 n 6$ & $0.07 \pm 0.01^{\mathrm{bB}}$ & $0.07 \pm 0.01^{\mathrm{bB}}$ & $0.16 \pm 0.06^{\mathrm{aB}}$ & $0.16 \pm 0.05^{\mathrm{abA}}$ & $0.16 \pm 0.02^{\mathrm{bA}}$ & $0.22 \pm 0.02^{\mathrm{aA}}$ & $0.05 \pm 0.01^{\mathrm{bB}}$ & $0.06 \pm 0.01^{\mathrm{bC}}$ & $0.12 \pm 0.02^{\mathrm{aB}}$ \\
\hline $\mathrm{C} 20: 4 n 6$ & $0.07 \pm 0.01^{\mathrm{aB}}$ & $0.06 \pm 0.01^{\mathrm{aB}}$ & $0.06 \pm 0.01^{\mathrm{aB}}$ & $0.45 \pm 0.06^{\mathrm{aA}}$ & $0.20 \pm 0.05^{\mathrm{cA}}$ & $0.31 \pm 0.09^{\mathrm{bA}}$ & $0.06 \pm 0.01^{\mathrm{bB}}$ & $0.06 \pm 0.00^{\mathrm{bC}}$ & $0.08 \pm 0.01^{\mathrm{aB}}$ \\
\hline $\begin{array}{c}\mathrm{C} 22: 3+ \\
\mathrm{C} 22: 4\end{array}$ & $0.07 \pm 0.01^{\mathrm{aB}}$ & $0.07 \pm 0.01^{\mathrm{aB}}$ & $0.10 \pm 0.04^{\mathrm{aB}}$ & $0.18 \pm 0.01^{\mathrm{aA}}$ & $0.10 \pm 0.02^{\mathrm{cA}}$ & $0.15 \pm 0.01^{\mathrm{bA}}$ & $0.04 \pm 0.01^{\mathrm{bC}}$ & $0.05 \pm 0.01^{\mathrm{bC}}$ & $0.08 \pm 0.00^{\mathrm{aB}}$ \\
\hline $\mathrm{C} 22: 5 n 3$ & $0.07 \pm 0.01^{\mathrm{bB}}$ & $0.09 \pm 0.02^{\mathrm{bB}}$ & $0.30 \pm 0.11^{\mathrm{aA}}$ & $0.30 \pm 0.06^{\mathrm{aA}}$ & $0.20 \pm 0.04^{\mathrm{bA}}$ & $0.23 \pm 0.06^{\mathrm{abA}}$ & $0.08 \pm 0.01^{\mathrm{bB}}$ & $0.08 \pm 0.00^{\mathrm{bB}}$ & $0.10 \pm 0.01^{\mathrm{aB}}$ \\
\hline SFA & $46.76 \pm 0.97^{A \mathrm{a}}$ & $47.62 \pm 0.53^{\mathrm{aB}}$ & $40.80 \pm 0.28^{\mathrm{bC}}$ & $46.51 \pm 0.47^{\mathrm{aA}}$ & $45.52 \pm 4.50^{\mathrm{aB}}$ & $49.59 \pm 1.79^{\mathrm{aA}}$ & $35.08 \pm 0.20^{\mathrm{cB}}$ & $53.42 \pm 0.19^{\mathrm{aA}}$ & $45.29 \pm 0.61^{\mathrm{bB}}$ \\
\hline MUFA & $48.03 \pm 1.23^{\mathrm{Ab}}$ & $48.57 \pm 0.64^{\mathrm{aA}}$ & $55.70 \pm 0.50^{\mathrm{bA}}$ & $46.29 \pm 0.69^{\mathrm{ac}}$ & $49.73 \pm 4.92^{\mathrm{aA}}$ & $45.37 \pm 1.76^{\mathrm{aC}}$ & $53.05 \pm 0.29^{\mathrm{aA}}$ & $41.72 \pm 0.17^{\mathrm{cB}}$ & $49.63 \pm 0.53^{\mathrm{bB}}$ \\
\hline PUFA & $5.21 \pm 0.93^{\mathrm{Ac}}$ & $3.81 \pm 0.13^{\mathrm{bB}}$ & $3.50 \pm 0.43^{\mathrm{bA}}$ & $7.20 \pm 0.28^{\mathrm{aB}}$ & $4.70 \pm 0.49^{\mathrm{bA}}$ & $5.04 \pm 0.11^{\mathrm{bB}}$ & $11.87 \pm 0.12^{\mathrm{aA}}$ & $4.86 \pm 0.03^{\mathrm{bA}}$ & $5.09 \pm 0.25^{\mathrm{bB}}$ \\
\hline $\mathrm{CHOL}$ & $867.2 \pm 101.4^{\mathrm{aBB}}$ & $732.4 \pm 14.5^{\mathrm{aB}}$ & $739.7 \pm 31.0^{\mathrm{aB}}$ & $5192.4 \pm 899.6^{\text {aA }}$ & $3431.2 \pm 109.2^{\mathrm{aA}}$ & $2937.6 \pm 157.7^{\mathrm{aA}^{\mathrm{A}}}$ & $990.8 \pm 38.4^{\mathrm{aB}}$ & $963.1 \pm 168.4^{\mathrm{aB}}$ & $1160.3 \pm 36.4^{\mathrm{aB}}$ \\
\hline
\end{tabular}

Abbreviations: CA, calf; YB, young bull; CO, cow; CLA, conjugated linoleic acid; SFA, saturated fatty acid; MUFA, monounsaturated fatty acid; PUFA, polyunsaturated fatty acid; CHOL, cholesterol. Data (means $\pm \mathrm{SD}$ ) are expressed in mg FA/100 mg FAME (\%) and in mg cholesterol $/ \mathrm{kg}$; results of the analysis of variance by Tukey's test are shown: $p<0.05$, lowercase letters on the same row show significantly different values within each by-product for the three animals; capital letters in the same row show significantly different mean values within each individual animal for the by-products.

between $40.80 \%$ in cow and $47.62 \%$ in young bull)were slightly lower than their data $\left(43.62-48.51 \%{ }^{22}\right.$ and $46.05-$ $\left.49.25 \%{ }^{23)}\right)$; instead for MUFA and PUFA we registered higher and lower concentrations respectively rather than these two works. For MUFA we had a range from 48.03\%, in calf, to $55.70 \%$, in cow $\left(33.94-38.42 \%{ }^{22)}\right.$ and 32.08 $\left.42.08 \%{ }^{23}\right)$; and for PUFA we had a range between 3.50 , in cow, and $5.21 \%$, in calf $\left(15.04-20.48 \%{ }^{22}\right.$ and $\left.10.69-21.87 \%{ }^{23)}\right)$.

Also in subcutaneous fat, the principal classes were SFA and MUFA, showing not significant differences between the three bovine categories analysed and with a range between 45.52 and $49.59 \%$, and between 45.37 and $49.73 \%$, respectively. PUFA were present in considerably smaller amounts and with a significantly higher content in calf than the other two animals $(p<0.05)$, as it was observed for storage fat. In fact, CA subcutaneous fat report- ed more linoleic acid (C18:2 n6) than YB and CO, in the amount of $4.69 \%$. These results are in agreement with the study of Indurain et $a{ }^{2 .}{ }^{24}$ on the fatty acid profile of subcutaneous adipose tissue in young bulls. Other investigations were carried out on the fatty acid compositions of bulls and heifers. Schiavon and co-workers ${ }^{25)}$ showed a similar MUFA content in beef subcutaneous fat, whereas SFA and PUFA were present in higher and lower amount compared to our results. Noci et $a l .{ }^{26}$ have observed low SFA concentration in heifers and MUFA and PUFA with higher values than our samples.

In the bone marrow, animals showed more variability in SFA and MUFA contents. SFA were present in higher amount in YB sample, with an average content of 53.42\%, followed with significant lower values by CO $(45.29 \%)$ and CA $(35,08 \%)$. On the other hand, MUFA were more abun- 
dant in $\mathrm{CA}(53.05 \%)$, followed by $\mathrm{CO}(49.63 \%)$ and $\mathrm{YB}$ $(41.72 \%)$. As already seen in the previous two by-products, PUFA presented low concentrations and CA was the sample with the highest percentage, due to the important amount in linoleic acid (10.56\%) compared to YB and CO.

The conjugated linoleic acid (CLA) was present in all samples in a range between $0.23 \%$ of the CA's bone marrow and $0.70 \%$ of the YB's bone marrow.

The low PUFA content of the analysed cattle's by-products confirm what it is already report in literature. Bovines are ruminants and the rumen microflora conduct a hydrogenation process of unsaturated fatty acids making them saturated, increasing the total SFA amount ${ }^{27)}$.

Compared to previous works on fatty acid profile of bovine samples ${ }^{24,28,29)}$, this study, obtained with a fast GC-FID, allows to get a large number of fatty acids in just 7 minutes of run time.

\subsection{Determination of triacylglycerols}

Because of fatty acids make up the bulk of a triacylglycerol molecule, this study also focused on triacylglycerols (TGs) composition of samples, using a fast GC-FID analysis with a time of less than $13 \mathrm{~min}$. As reported in Table 3, six classes of triacylglycerols were identified and quantified in all by-products, corresponding to TGs with 42 to 52 carbon number $(\mathrm{CN})$.

All the by-products showed a high content of long-chain TGs (CN48, CN50 and CN52), with CN50 as the most abundant class, expressing about the $50 \%$ of the total TGs in samples. Following the TGs with CN48 were present with a content of about $18-26 \%$ and in decreasing amount the CN52 ( 12-19\%), CN46( -5-13\%), CN44( 1-4\%) and CN42 $(\sim 0.2-0.9 \%)$ classes. These results reflect a close relationship between the fatty acids and TGs content of samples. Indeed, a high content in TGs CN50 and CN48 was coincident with high levels of C18:1, C18:0, C16:0 and C14:0.

In storage fat, the three animals did not show significant differences in TGs content from CN42 to CN48. Whereas for the long-chain TGs, CN50 and CN52, CA samples presented a significantly lower and higher content, respectively, than the other two animals. More variability was observed for the TG content in subcutaneous fat and mainly for the long-chain classes, CN50 and CN52. In the first case, $\mathrm{CO}$ showed the highest content followed by $\mathrm{YB}$ and $\mathrm{CA}$, whereas the CN52 class was more concentrated in CA than YB and CO. Finally, the TG distribution in the bone marrow samples were significantly different among the three bovine categories. In particular, TGs content from CN42 to CN48 was significantly high in YB, followed by CA and CO; on the contrary, TGs with CN50 were present in high amount in CO and TGs with CN52 in CA (Table 3).

\subsection{Cholesterol content of by-products}

Cholesterol is a sterol of animal origin which belong to lipid unsaponificable fraction. It is predominantly localized in the membrane of blood cells and it can affect their fluidity $^{30}$.

As shown in Table 2, no differences $(p<0.05)$ were carried out among the three animals for each by-product, whereas each animal showed a significantly higher cholesterol content in subcutaneous fat compared to the storage fat and bone marrow. This result was plausible being cholesterol a leading and fundamental component of cell membranes. In the other two by-products, storage fat and bone marrow, no significant differences were found ranging from $732.4 \mathrm{mg} / \mathrm{kg}$ in the storage fat of YB to $1160.3 \mathrm{mg} / \mathrm{kg}$ in the bone marrow of CO. Despite the lack of literature about cholesterol content in beef by-products, our results are higher than other studies. Several authors ${ }^{31-34}$ investigated the cholesterol amount on beef meat and all of them had lower cholesterol content than our by-products (460.8$490.7^{311}, 511.0-630.0^{32)}, 30.0-340.4^{33)}$ and $360.3-410.5^{34)} \mathrm{mg}$ cholesterol $/ \mathrm{kg})$.

\subsection{Phospholipids content of bone marrow}

The phospholipids content and the distribution of individual phospholipid species were determined only in the

Table 3 Triacylglycerols composition of the different by-products.

\begin{tabular}{|c|c|c|c|c|c|c|c|c|c|}
\hline \multirow{2}{*}{ TGs } & \multicolumn{3}{|c|}{ Storage fat } & \multicolumn{3}{|c|}{ Subcutaneous fat } & \multicolumn{3}{|c|}{ Bone marrow } \\
\hline & $\mathrm{CA}$ & YB & $\mathrm{CO}$ & $\mathrm{CA}$ & YB & $\mathrm{CO}$ & $\mathrm{CA}$ & YB & $\mathrm{CO}$ \\
\hline $\mathrm{CN} 42$ & $0.5 \pm 0.2^{\mathrm{aA}}$ & $0.4 \pm 0.0^{\mathrm{aB}}$ & $0.5 \pm 0.0^{\mathrm{aA}}$ & $0.4 \pm 0.1^{\mathrm{aA}}$ & $0.4 \pm 0.0^{\mathrm{abB}}$ & $0.3 \pm 0.0^{\mathrm{bB}}$ & $0.4 \pm 0.0^{\mathrm{bA}}$ & $0.9 \pm 0.1^{\mathrm{aA}}$ & $0.2 \pm 0.0^{\mathrm{cC}}$ \\
\hline CN44 & $2.9 \pm 0.5^{\mathrm{aA}}$ & $2.9 \pm 0.1^{\mathrm{aB}}$ & $3.2 \pm 0.1^{\mathrm{aA}}$ & $2.3 \pm 0.1^{\mathrm{bB}}$ & $2.5 \pm 0.1^{\mathrm{aC}}$ & $2.3 \pm 0.1^{\mathrm{bB}}$ & $2.1 \pm 0.0^{\mathrm{bB}}$ & $4.1 \pm 0.2^{\mathrm{aA}}$ & $1.2 \pm 0.0^{\mathrm{cC}}$ \\
\hline CN46 & $11.3 \pm 0.5^{\mathrm{aA}}$ & $11.4 \pm 0.3^{\mathrm{aB}}$ & $11.7 \pm 0.3^{\mathrm{aA}}$ & $9.6 \pm 0.2^{\mathrm{aB}}$ & $9.5 \pm 0.3^{\mathrm{aC}}$ & $9.0 \pm 0.2^{\mathrm{bB}}$ & $7.6 \pm 0.1^{\mathrm{bC}}$ & $12.5 \pm 0.3^{\mathrm{aA}}$ & $5.5 \pm 0.1^{\mathrm{cC}}$ \\
\hline $\mathrm{CN} 48$ & $26.0 \pm 0.7^{\mathrm{aA}}$ & $26.0 \pm 0.6^{\mathrm{aA}}$ & $25.5 \pm 0.2^{\mathrm{aA}}$ & $24.7 \pm 0.3^{\mathrm{aB}}$ & $24.8 \pm 0.4^{\mathrm{aB}}$ & $24.6 \pm 0.4^{\mathrm{aB}}$ & $19.2 \pm 0.1^{\mathrm{bC}}$ & $24.7 \pm 0.2^{\mathrm{aB}}$ & $18.0 \pm 0.2^{\mathrm{cC}}$ \\
\hline CN50 & $42.1 \pm 1.2^{\mathrm{bB}}$ & $43.0 \pm 0.6^{\mathrm{abB}}$ & $43.5 \pm 0.5^{\mathrm{aC}}$ & $44.2 \pm 0.4^{\mathrm{cA}}$ & $48.7 \pm 0.7^{\mathrm{bA}}$ & $51.2 \pm 0.5^{\mathrm{aB}}$ & $44.5 \pm 0.2^{\mathrm{bA}}$ & $44.7 \pm 0.3^{\mathrm{bB}}$ & $56.1 \pm 0.3^{\mathrm{aA}}$ \\
\hline CN52 & $17.2 \pm 0.4^{\mathrm{aC}}$ & $16.3 \pm 0.9^{\mathrm{bA}}$ & $15.6 \pm 0.2^{\mathrm{bB}}$ & $18.8 \pm 0.7^{\mathrm{aB}}$ & $14.2 \pm 1.1^{\mathrm{bB}}$ & $12.6 \pm 0.4^{\mathrm{cC}}$ & $26.1 \pm 0.2^{\mathrm{aA}}$ & $13.1 \pm 0.4^{\mathrm{cB}}$ & $19.0 \pm 0.3^{\mathrm{bA}}$ \\
\hline
\end{tabular}

Abbreviations: CA, calf; YB, young bull; CO, cow. Data (means \pm SD) are expressed in $\mathrm{g}$ TGs/100 g of fat (\%); results of the analysis of variance by Tukey's test are shown: $p<0.05$, lowercase letters on the same row show significantly different values within each by-product for the three animals; capital letters in the same row show significantly different mean values within each individual animal for the by-products. 


\section{S. Marzocchi, F. Pasini, C. Baldinelli et al.}

Table 4 Phospholipids (PLs) content in bone marrow of calf, young bull and cow.

\begin{tabular}{cccc}
\hline PLs & CA & YB & CO \\
\hline PC & $28.0 \pm 2.8^{\mathrm{a}}$ & $16.2 \pm 0.5^{\mathrm{b}}$ & $17.6 \pm 1.5^{\mathrm{b}}$ \\
SM & $21.2 \pm 0.8^{\mathrm{a}}$ & $10.8 \pm 0.6^{\mathrm{c}}$ & $12.4 \pm 0.8^{\mathrm{b}}$ \\
Total PLs & $49.2 \pm 3.5^{\mathrm{a}}$ & $27.1 \pm 1.0^{\mathrm{b}}$ & $30.0 \pm 2.1^{\mathrm{b}}$ \\
\hline
\end{tabular}

Abbreviations: CA, calf; YB, young bull; $\mathrm{CO}$, cow. Data (means $\pm \mathrm{SD}$ ) are expressed in $\mathrm{mg} / \mathrm{g}$ of fat; results of the analysis of variance by Tukey's test are shown: $p<0.05$, different letters show significantly different values within each individual animal for bone marrow sample.

bone marrow of the three different bovine categories (Table 4). Two phospholipids, phosphatidylcholine (PC) and sphingomyelin (SM), were detected in all the samples. According to literature ${ }^{10,35)}$, PC was the major phospholipid in all the three animals, accounting about the $60 \%$ of the total phospholipids content, because it is the key building blocks of membrane bilayers. In all samples, SM was present in lower amount compared to PC but it plays an important role in animals because it is a substitute for PC as a building block of membranes.

Besides, CA's bone marrow showed the highest content both in total and individual phospholipids compared to YB and CO samples. This result can be expected since CA is a young growing animal and its cell membranes need more phospholipids, critical to cells' ability to function and grow $^{36)}$.

\section{Conclusion}

Because of the lack of literature on the lipid quality of meat by-products, this study represents a first screening of bioactive lipids in different wastes produced by bovine meat industry. The obtained results underline that subcutaneous fat is a non-homogeneous waste with a highly variable composition. Nevertheless, as expected, subcutaneous fat showed the highest cholesterol content compared to the other by-products, because cholesterol is involved in the structure of the membranes that are present where the storage fat is low. On the other hand, the storage fat and especially the bone marrow presented a high fat amount and they were characterized by a low cholesterol content and important concentration of some essential fatty acids (linoleic acid, $\alpha$ and $\gamma$ linolenic acid, eicosadienoic acid and arachinodic acid). In particular, calf showed the maximum content of oleic acid, linoleic acid and phospholipids, but also the highest content of cholesterol in the subcutaneous fat rather than young bull and cow. Conversely, young bull presented the lowest cholesterol amount and cow the highest TG content, especially CN48 class.
According to this first evaluation, it could be assumed a future application of these bovine by-products for other purposes. Appropriate research and development activity can help to convert these animal by-products in bioactive components for nutritional properties and other non-food applications like pharmaceuticals, cosmetics or energy.

In particular, a next step of this study will be a crystallization of the lipid fraction of by-products in order to separate and increase the percentage of some interesting bioactive compounds.

\section{Acknowledgements}

This study was funded by the Cluster Agrifood project "SOstenibilità della FIliera Agroalimentare italiana - SO.FI. A" (CTN01_00230_450760). The authors also thank INALCA S.p.A. who provided all the samples of this investigation.

The authors declare no conflict of interest.

\section{References}

1) Lafarga, T.; Hayes, M. Bioactive peptides from meat muscle and by-products: generation, functionality and application as functional ingredients. Meat Sci. 98, 227-239 (2014).

2) Hsieh, Y.P.; Ofori, J.A. Food-grade proteins from animal by-products: Their usage and detection methods. in Handbook of Analysis of Edible Animal By-Products (Nollet, L.M.L.; Toldrà, F. eds.), CRC Press, Boca Raton, pp. 13-31 (2011).

3) Toldrà, F.; Concepción Aristoy, M.; Mora, L.; Reig, M. Innovations in value-addition of edible meat by-products. Meat Sci. 92, 290-296 (2012).

4) Sikorski, Z.E.; Sinkiewicz, I. The Role of lipids in meat. in Chemical, Biological, and Functional Aspects of Food Lipids (Sikorski, Z.E.; Sinkiewicz, I. eds.), CRC Press, Boca Raton, pp. 237-340 (2010).

5) Bittante, G.; Andrighetto, I.; Ramanzin, M. Tecniche di produzione animale (Bittante, G.; Andrighetto, I.; Ramanzin, M. eds.), Liviana Ed., Novara (2005).

6) Rombaut, R.; Van Camp, J.; Dewettinck, K. Phosphoand sphingolipid distribution during processing of milk, butter and whey. Int. J. Food Sci. Tech. 41, 435443 (2006).

7) Sánchez-Juanes, F.; Alonso, J.M.; Zancada, L.; Hueso, P. Distribution and fatty acid content of phospholipids from bovine milk and bovine milk globule membranes. Int. Dairy J. 19, 273-278(2009).

8) Donato, P.; Cacciola, F.; Cichello, F.; Russo, M.; Dugo, P.; Mondello, L. Determination of phospholipids in milk samples by mean of hydrophilic interaction liquid 
chromatography coupled to evaporative light scattering mass spectrometry detection. J. Chromatogr. A 1218, 6476-6482(2005).

9) Thompson, A.K.; Haisman, D.; Singh, H. Physical stability of liposomes prepared from milk fat globule membrane and soya phospholipids. J. Agr. Food Chem. 54, 6390-6397(2006).

10) Dannenberger, D.; Nuernberg, G.; Scollan, N.; Ender, K.; Nuernberg, K. Diet alters the fatty acid composition of individual phospholipid classes in beef muscle. J. Agr. Food Chem. 55, 452-460 (2007).

11) Folch, J.; Lees, M.; Sloane Stanley, G.H. A simple method for isolation and purification of total lipids for animal tissues. J. Biol. Chem. 226, 497-509 (1957).

12) Boselli, E.; Velazco, V.; Caboni, M.F.; Lercker, G. Pressurized liquid extraction of lipids for the determination of oxysterols in egg-containing food. J. Chromatogr. A 917, 239-244 (2001).

13) Christie, W.W. A simple procedure for rapid transmethylation of glycerolipids and cholesteryl esters. $J$. Lipid Res. 23, 1072-1075(1982).

14) Verardo, V.; Gómez-Caravaca, A.M.; Gori, A.; Losi, G.; Caboni, M.F. Bioactive lipids in the butter production chain from Parmigiano Reggiano cheese area. J. Sci. Food Agr. 93, 3625-3633 (2013).

15) Guerra, E.; Verardo, V.; Caboni, M.F. Determination of bioactive compounds in cream obtained as a by-product during cheese-making: Influence of cow's diet on lipid quality. Int. Dairy J. 42, 16-25(2015).

16) Sander, B.D.; Addis, P.B.; Park, S.W.; Smith, D.E. Quantification of cholesterol oxidation products in a variety of foods. J. Food Protect. 2, 109-114(1989).

17) Sweeley, C.C.; Bentley, R.; Makita, M.; Wells, W.W. Gasliquid chromatography of trimethylsilyl derivates of sugar and related substances. J. Am. Chem. Soc. 85, 2497-2507 (1963).

18) Guerra, E.; Downey, E.; O’Mahony, J.A.; Caboni, M.F.; O'Shea, C.A.; Ryan, A.C.; Kelly, A.L. Influence of duration of gestation on fatty acid profiles on human milk. Eur. J. Lipid Sci. Tech. 118, 1775-1787(2016).

19) Avalli, A.; Contarini, G. Determination of phospholipids in dairy products by SPE/HPLC/ELSD. J. Chromatogr. A 1071, 185-190 (2005).

20) Verardo, V.; Gómez-Caravaca, A.M.; Montealegre, C.; Segura-Cerretero, A.; Caboni, M.F.; Fernández-Gutiérrez, A.; Bendini, A. Optimization of a solid phase extraction method and hydrophilic interaction liquid chromatography coupled to mass spectrometry for the determination of phospholipids in virgin olive oil. Food. Re. Int. 54, 2083-2090 (2013).

21) Scollan, N.; Hocquette, J.F.; Nuernberg, K.; Dannenberger, D.; Richardson, I.; Moloney, A. Innovations in beef production system that enhance the nutritional and health value of beef lipids and they relationship with meat quality. Meat Sci. 74, 17-33(2006).

22) De Smet, S.; Webb, E.C.; Claesy, E.; Uytterhaegen, L.; Demeyer, D.I. Effect of dietary energy and protein levels on fatty acid composition of intramuscular fat in double-muscled Belgian Blue Bulls. Meat Sci. 56, 73-79 (2000).

23) Brugiapaglia, A.; Lussiana, C.; Destefanis, G. Fatty acid profile and cholesterol content of beef at retail of Piemontese, Limousin and Friesian breeds. Meat Sci. 96, 568-573(2014).

24) Indurain, G.; Beriain, M.G.; Goñi, M.V.; Arana, A.; Purroy, A. Composition and estimation of intramuscular and subcutaneous fatty acid composition in Spanish young bulls. Meat Sci. 73, 326-334(2006).

25) Schiavon, S.; Pellattiero, E.; Cecchinato, A.; Tagliapietra, F.; Dannenberger, D.; Nuernberg, K.; Nuernberg, G.; Bittante, G. The influence of different sample preparation procedures on the determination of fatty acid profiles of beef subcutaneous fat, liver and muscle by gas chromatography. J. Food Comp. Anal. 50, 10-18(2016).

26) Noci, F.; Monahan, F.J.; French, P.; Moloney, A.P. The fatty acid composition of muscle fat and subcutaneous adipose tissue of pasture-fed beef heifers: influence of the duration of grazing. J. Anim. Sci. 83, 1167-1178 (2005).

27) Mapiye, C.; Dugan, M.E.; Juarez, M.; Basarab, J.A.; Baron, V.S.; Turner, T.; Yang, X.; Aldai, N.; Aalhus, J.L. Influence of alpha-tocopherol supplementation on trans-18:1 and conjugated linoleic acid profiles in beef from steers fed a barley-based diet. Animal 6, 18881896 (2012).

28) Aharoni, Y.; Orlov, A.; Brosh, A. Effects of high-forage content and oilseed supplementation of fattening diets on conjugated linoleic acid (CLA) and trans fatty acids profiles of beef lipid fractions. Anim. Feed Sci. Tech. 117, 43-60 (2004).

29) Moreno, T.; Keane, M.G.; Noci, F.; Moloney, A.P. Fatty acid composition of $M$. Longissimus dorsi from Holstein-Friesian steers of New Zealand and European/ American descent and from Belgian Blue x HolsteinFriesian steers, slaughtered at two weights/ages. Meat Sci. 78, 157-169 (2008).

30) Boselli, E.; Rodriguez-Estrada, M.T.; Fedrizzi, G.; Caboni, M.F. Cholesterol photosensitised oxidation of beef meat under standard and modified atmosphere at retail conditions. Meat Sci. 81, 224-229(2009).

31) Cifuni, G.F.; Napolitano, F.; Riviezzi, A.M.; Braghieri, A.; Girolami, A. Fatty acid profile, cholesterol content and tenderness of meat from Podolian young bulls. Meat Sci. 67, 289-297(2004).

32) Almeida, J.C.; Perassolo, M.S.; Camargo, J.L.; Bragagnolo, N.; Gross, J.L. Fatty acid composition and cholesterol content of beef and chicken meat in Southern 


\section{S. Marzocchi, F. Pasini, C. Baldinelli et al.}

Brazil. Braz. J. Pharm. Sci. 42, 109-117(2006).

33) Baggio, S.R.; Bragagnolo, N. The effect of heat treatment on the cholesterol oxides, cholesterol, total lipid and fatty acid contents of processed meat products. Food Chem. 95, 611-619(2006).

34) Muchenje, V.; Hugo, A.; Dzama, K.; Chimonyo, M.; Strydom, P.E.; Raats, J.G. Cholesterol levels and fatty acid profiles of beef from three cattle breeds raised on natural pasture. J. Food Comp. Anal. 22, 354-358
(2009).

35) Descalzo, A.M.; Insani, E.M.; Pensel, N.A. Light-Scattering detection of phospholipids resolved by HPLC. Lipids 38, 999-1003(2003).

36) Wood, J.D.; Enser, M.; Fisher, A.V.; Nute, G.R.; Sheard, P.R.; Richardson, R.I.; Hughes, S.I.; Whittington, F.M. Fat deposition, fatty acid composition and meat quality: A review. Meat Sci. 78, 343-358(2008). 